ECCOMAS

Proceedia
COMPDYN 2021

$8^{\text {th }}$ ECCOMAS Thematic Conference on Computational Methods in Structural Dynamics and Earthquake Engineering M. Papadrakakis, M. Fragiadakis (eds.)

Streamed from Athens, Greece, 28 - 30 June 2021

\title{
SEISMIC BEHAVIOR OF SUBSTANDARD EXTENDED RECTANGULAR RC COLUMNS JACKETED WITH SPRAYED GFRM
}

\author{
Muhsin Can Luleci ${ }^{1 \mathrm{~A}}$, Bilal Sari ${ }^{1 \mathrm{~B}}$, Ugur Demir $^{2}$, Muhammed Marasli $^{3}$ and Alper Ilki ${ }^{4}$ \\ ${ }^{1}$ MSc Student \\ Istanbul Technical University, 34469, Maslak, Istanbul \\ e-mail: A: 1uleci19@itu.edu.tr; B: sarib19@itu.edu.tr \\ ${ }^{2} \mathrm{PhD}$, Research Assistant \\ Hakkari University, Hakkari \\ e-mail: udemir@itu.edu.tr \\ ${ }^{3}$ Member of Board of Directors \\ Fibrobeton Yapi Elemanlari, 34810, Kavacik, Istanbul \\ e-mail: muhammed@fibrobeton.com.tr \\ ${ }^{4}$ Professor \\ Istanbul Technical University, 34469, Maslak, Istanbul \\ e-mail: ailki@itu.edu.tr
}

\begin{abstract}
In earthquake prone areas, columns of many relatively old $R C$ (reinforced concrete) structures do not comply with the current seismic design codes, particularly in developing countries. Low concrete strength, improper seismic detailing of transverse reinforcement and high axial stresses on the columns are common problems causing lack of sufficient ductility under seismic forces. External jacketing of substandard columns by spraying GFRM (glass fiber reinforced mortar) is a new, practical and feasible method to overcome these deficiencies, particularly for the cases where access to the structural members is limited. In this study, the effects of cross-sectional aspect ratio $(h / b)$ of columns on effectiveness of external jacketing with sprayed GFRM are investigated experimentally. For this purpose, four full scale RC columns were tested under constant axial load $\left(0.35 f_{c} A_{g}\right)$ and cyclic lateral displacement reversals before and after seismic retrofit with sprayed GFRM jacket. The cross-sectional aspect ratios of two columns were 2.0, whereas the cross-sectional aspect ratio was 4.0 for the other two columns. The structural responses of the columns are discussed through hysteretic and envelope load-displacement curves. The test results show that sprayed GFRM jacketing improves lateral ductility of the substandard columns significantly. It is also shown that the method is effective for the columns with high cross-sectional aspect ratios.
\end{abstract}

Keywords: Column, GFRM, Reinforced Concrete, Seismic 


\section{INTRODUCTION}

There are many buildings all over the world that do not comply with the requirements of current seismic design codes or with the requirements of their construction times. The poor seismic performance of buildings with typical deficiencies of structural members (i.e. columns) such as low strength concrete, inadequate detailing and insufficient transverse reinforcement may cause a considerable number of casualties and economic losses during severe earthquakes. Previous devastating earthquakes (i.e. 1994 Northridge, 1995 Kobe, 1999 Kocaeli, 2011 Van, 2020 Elazig and Izmir earthquakes) have also demonstrated the vulnerability of substandard RC columns exposed to seismic actions demanding large inelastic deformations [1-2]. To mitigate this risk, many studies on seismic retrofitting of substandard columns were conducted in the last decades. Because the major problem for the substandard building stock stems from the lack of lateral strength, ductility and stiffness, the external jacketing method using fiber reinforced polymers (FRPs) has gained popularity for the enhancement of the seismic performance of substandard RC members [e.g. 3-9]. The proven efficiency of this innovative solution in terms of providing additional confinement, leads to improved seismic resistance in terms of lateral load capacity and inelastic deformation capabilities of substandard RC members. Recent researches have shown that usage of other innovative materials such as textile reinforced mortar [e.g. 10-11] or fiber reinforced mortar [12] for external confinement is also a promising retrofitting solution for reinforced concrete and masonry members [13].

Therefore, this paper is aimed at improving the seismic resistance of extended rectangular substandard RC columns through sprayed GFRM (glass fiber reinforced mortar) jacketing. Towards this aim, preliminary results of an experimental study conducted on full-scale substandard RC columns of different cross-sectional aspect ratios (2.0 and 4.0) are presented in this paper. The study examines the impact of reversed cyclic lateral loading on the columns before and after application of proposed external jacketing method.

\section{EXPERIMENTAL WORK}

\subsection{Specimen details and test setup}

In the scope of the study, a total of 4 cantilever columns were cast to assess the efficiency of sprayed GFRM jacketing on seismic behavior of substandard RC columns. The columns had dimensions of $200 \mathrm{~mm} \times 400 \mathrm{~mm}$ and $200 \mathrm{~mm} \times 800 \mathrm{~mm}$, corresponding to cross-sectional aspect ratio $(\mathrm{h} / \mathrm{b})$ of 2.0 and 4.0 , respectively. The columns with $\mathrm{h} / \mathrm{b}$ of 2.0 and 4.0 were cast having a height of 1750 and $2100 \mathrm{~mm}$, respectively. For each aspect ratio, two columns were cast, one to be a reference column and the other with purpose of retrofitting. Each column incorporated an RC foundation block with dimensions of $900 \mathrm{~mm} \times 1300 \mathrm{~mm}(\mathrm{~h} / \mathrm{b}=2.0)$ or 1300 $\mathrm{mm} \times 1700 \mathrm{~mm}(\mathrm{~h} / \mathrm{b}=4.0)$ and height of $700 \mathrm{~mm}$. Columns were reinforced with 4 of $16 \mathrm{~mm}$ $(\mathrm{h} / \mathrm{b}=2.0)$ or 8 of $16 \mathrm{~mm}(\mathrm{~h} / \mathrm{b}=4.0)$ diameter longitudinal steel plain bars placed at the corners with a $30 \mathrm{~mm}$ concrete cover from the edge of the specimen to the outside of the longitudinal bars (Fig. 1). These bars had a yield strength of $292 \mathrm{MPa}$. Transverse reinforcement was provided in the form of plain bars with $10 \mathrm{~mm}$ diameter, which had a yield strength of $312 \mathrm{MPa}$. These bars were formed at $200 \mathrm{~mm}$ spacing center-to-center with 90 degrees hook angle at the test region representing existing substandard building stock. The geometric ratio of longitudinal reinforcement ratio was $1 \%$ and volumetric ratio of transverse reinforcements was $0.22 \%$ $(\mathrm{h} / \mathrm{b}=2.0)$ or $0.1 \%(\mathrm{~h} / \mathrm{b}=4.0)$, respectively, which were calculated according to current Turkish Building Earthquake Code [14]. All columns were constructed so as to be representative of 
the substandard columns not complying to any design codes. Concrete compressive strength at 28th day after casting was around $12 \mathrm{MPa}$, and at around the seismic test day (six months after casting) it was $14.1 \mathrm{MPa}$, which were obtained from $150 \mathrm{~mm} \times 300 \mathrm{~mm}$ standard cylinders. The columns were tagged as $\mathrm{C} 2$ (reference specimen with $\mathrm{h} / \mathrm{b}=2.0$ ), $\mathrm{C} 2-\mathrm{R}$ (retrofitted specimen with $\mathrm{h} / \mathrm{b}=2.0$ ), $\mathrm{C} 4$ (reference specimen with $\mathrm{h} / \mathrm{b}=4.0$ ) and $\mathrm{C} 4-\mathrm{R}$ (retrofitted specimen with $\mathrm{h} / \mathrm{b}=4.0$ ). The columns were strengthened with sprayed GFRM that had $4.5 \%$ glass fiber content by weight. The average 28-day compressive strength of five standard $50 \mathrm{~mm}$ cubic GFRM specimens was obtained in accordance with ASTM C109 [15] as 41.4 MPa.
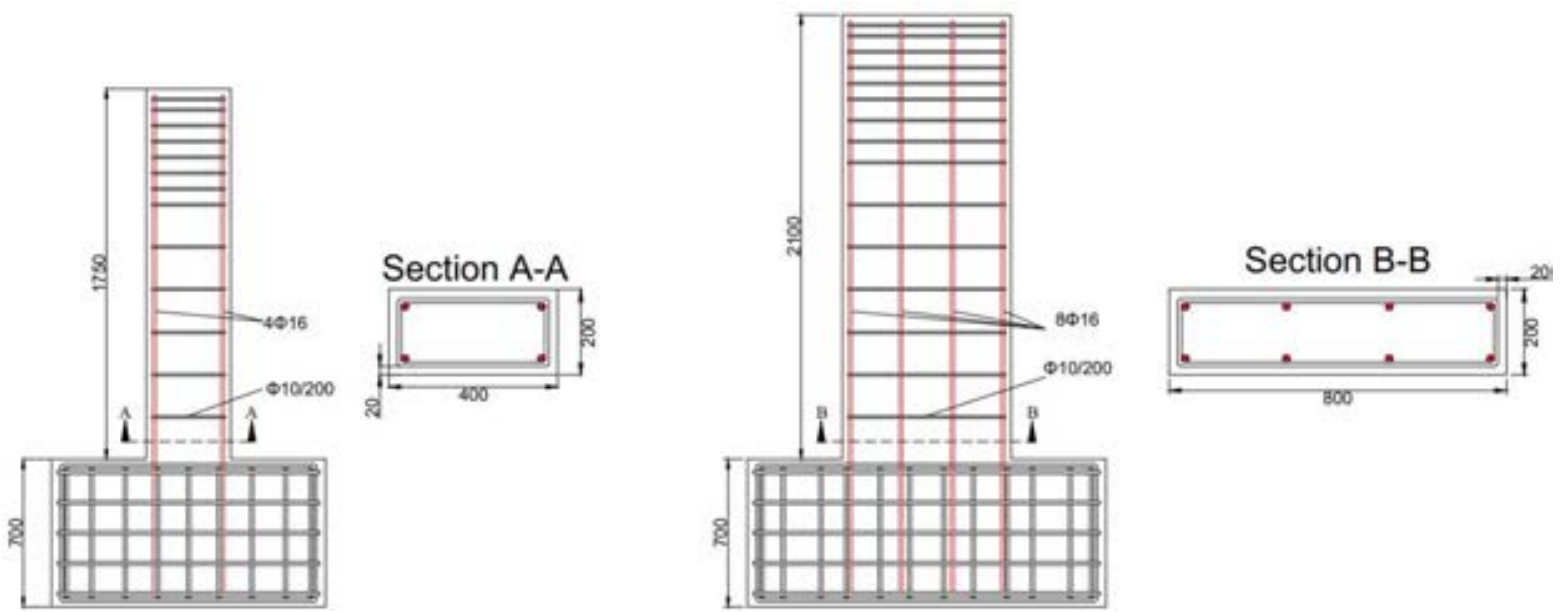

Figure 1: Reinforcement details of the columns. Note: All dimensions are in $\mathrm{mm}$

The general view of the test setup and measurement system consisting of load cells, potentiometers and strain gauges are shown in Fig. 2. The data from the potentiometers, load cells, and electrical resistance strain gauges were collected by means of a data logger. TML YFLA5 post-yield strain-gauges and TML FLA-5 foil strain-gauges were mounted on longitudinal and transverse reinforcements, respectively. The types and measurement lengths of potentiometers are shown in Fig. 2. In this figure, for instance, SLPS 50 denotes the potentiometer with a $50 \mathrm{~mm}$ stroke length. Specimens were fixed to the strong floor of the laboratory by means of six high strength $36 \mathrm{~mm}$ diameter bolts. Prior to the seismic tests, the axial load was applied by means of a manually force-controlled hydraulic jack with $2200 \mathrm{kN}$ capacity. After application of vertical constant load, reversed cyclic lateral displacement protocol was applied to the column by means of a horizontal hydraulic actuator with a $\pm 300 \mathrm{kN}$ and $\pm 400 \mathrm{~mm}$ force and displacement capacity, respectively. Each target displacement had two repeated cycles. The reversed cyclic lateral loading was applied considering increasing drift ratios in pushing and pulling directions that corresponded to $\pm 0.0005, \pm 0.001, \pm 0.002, \pm 0.003, \pm 0.004, \pm 0.005$, $\pm 0.0075, \pm 0.01, \pm 0.015, \pm 0.02, \pm 0.025, \pm 0.03, \pm 0.04, \pm 0.05, \pm 0.06$ and \pm 0.07 drift ratios according to ACI $374.2 \mathrm{R}-13$ [16]. Tests were not terminated until the failure (at least $25 \%$ loss of axial and/or lateral load capacities) was observed. 


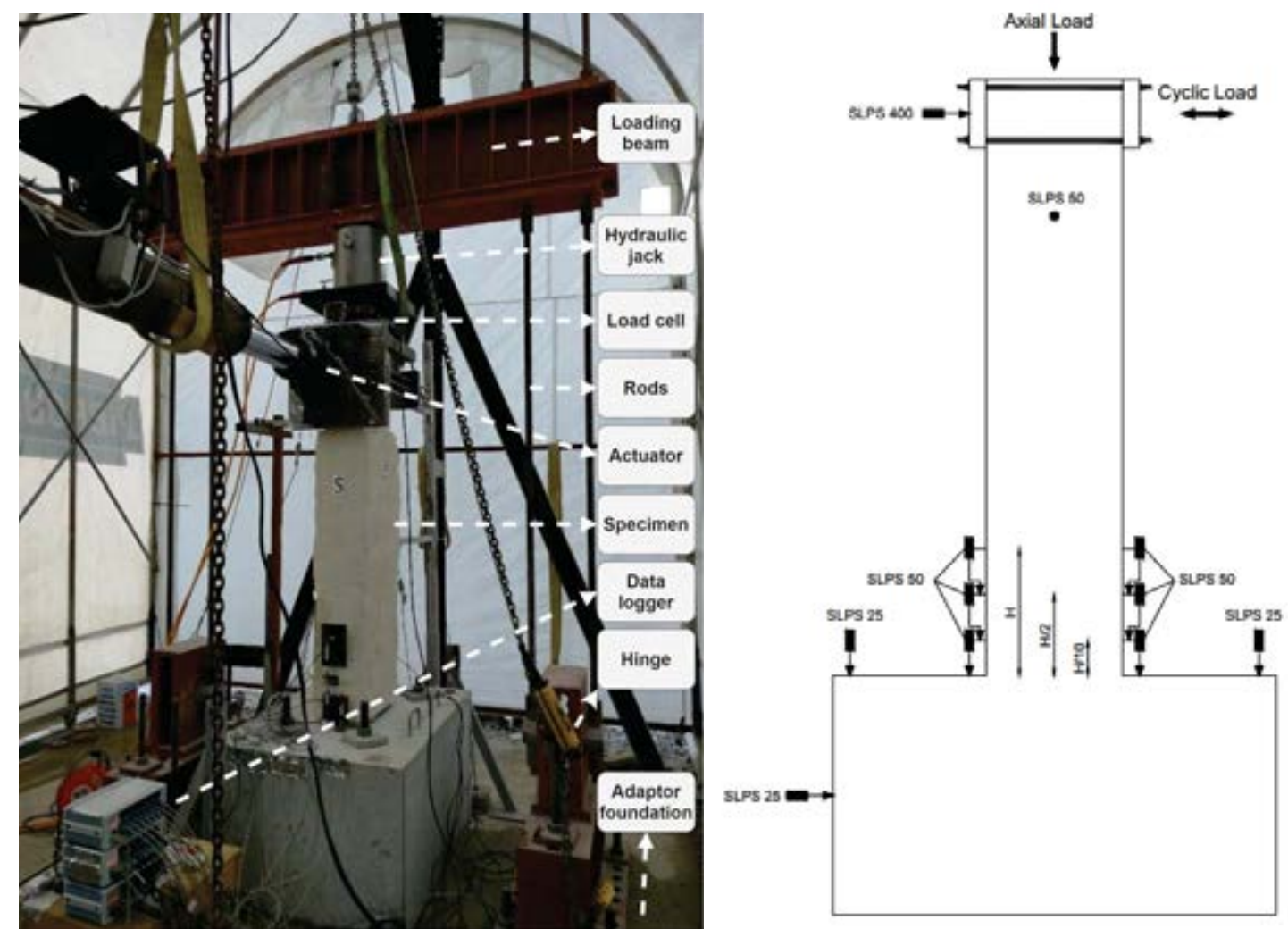

Figure 2: Seismic test setup and instrumentation

\subsection{Retrofitting procedure}

The columns C2-R and C4-R were prepared to be strengthened by rounding off their corners with a radius of $30 \mathrm{~mm}$. After preparing the surface by cleaning the dust to provide saturation between concrete and GFRM, spraying of GFRM started. Then, GFRM was sprayed by using a spraying gun to the surface of the column. The thickness of GFRM jacket for the column C2-R varied between $25 \mathrm{~mm}$ and $35 \mathrm{~mm}$, whereas for the column C4-R, this thickness was between $25 \mathrm{~mm}$ and $45 \mathrm{~mm}$. This enlarging thicknesses towards the center of the column edges were proposed to enhance the lateral confinement pressure provided by the jacket. Chopped glass fibers of $32 \mathrm{~mm}$ length were used in this composite material. Technical properties of the fibers provided by the manufacturer are shown in Table 1. In order to avoid local damages in the GFRM near the column foundation, a $30 \mathrm{~mm}$ of vertical gap was left between the GFRM and the column-foundation interface. The process of strengthening is shown in Fig. 3.

Table 1: Chopped glass fiber technical properties

\begin{tabular}{ll}
\hline Properties & Value \\
\hline Average Filament Diameter $(\mu \mathrm{m})$ & 19 \\
Specific Gravity $\left(\mathrm{gr} / \mathrm{m}^{3}\right)$ & 2.68 \\
Thickness $(\mathrm{mm})$ & $0.8-0.9$ \\
Tensile Strength $(\mathrm{MPa})$ & $1000-1700$ \\
Elastic Modulus $(\mathrm{GPa})$ & 72 \\
\hline
\end{tabular}




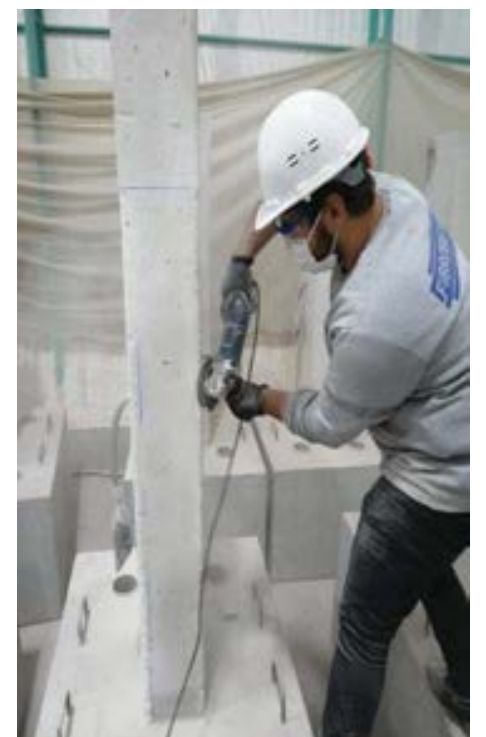

(a)

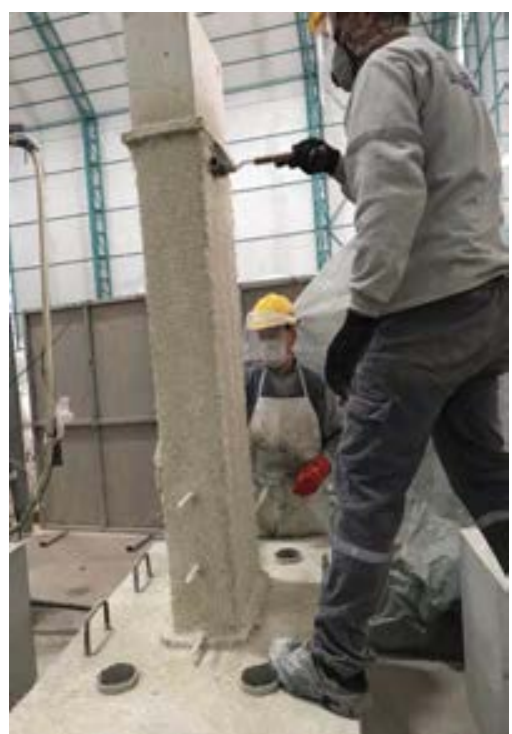

(b)

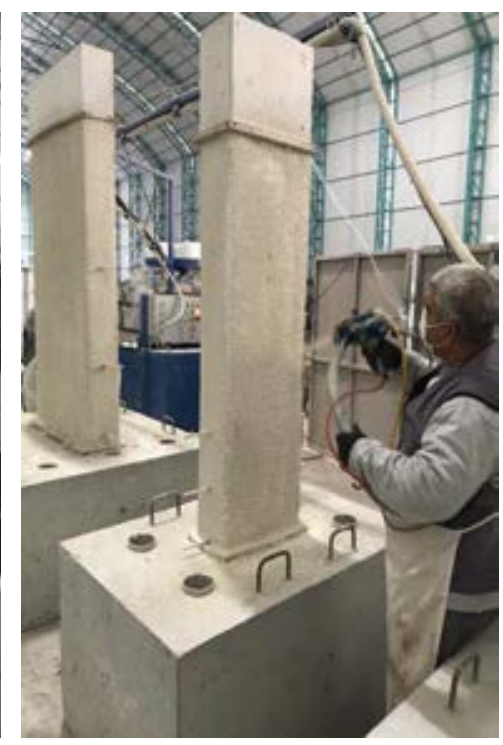

(c)

Figure 3: Strengthening process of the columns with GFRM a) rounding off the corners, b) rolling GFRM to distribute uniformly, c) spraying

\subsection{Test results}

The columns were tested under constant axial load and reversal cyclic lateral loading about six months after casting. During the tests, axial load was kept constant at $0.35 f^{\prime} c h$ for all specimens, where $f^{\prime} c$ is the compressive strength of concrete, $b$ and $h$ are the width and depth of the column cross-sections. The lateral load-displacement hysteretic curves of the columns and their envelopes are shown in Figs. 4 and 5. The maximum lateral load capacities in pushing and pulling directions are shown in Table 2. For the reference columns C2 and C4, peak lateral loads were achieved at around $1 \%$ and $0.75 \%$ drift ratio, respectively. The damage progressed for these columns sequentially with crushing and spalling of concrete cover which was followed by buckling of longitudinal rebars. Yielding of longitudinal reinforcement did not occur in these columns. For the reference columns, tests were terminated with $68 \%$ and $77 \%$ loss of lateral strength, respectively. On the other hand, due to the additional confinement provided by sprayed GFRM, retrofitted columns C2-R and C4-R exhibited a more ductile behavior with respect to their reference counterparts. This additional confinement led to delayed buckling of longitudinal bars which results with more ductility. Moreover, longitudinal reinforcements of strengthened specimens yielded before strength degradation, indicating that failure was not governed by crushing of concrete merely. For retrofitted columns C2-R and $\mathrm{C} 4-\mathrm{R}$, peak loads were achieved at $1 \%$ drift ratio and $0.75 \%$ drift ratio, respectively. After this point, strength loss initiated due to an increase in crack widths at the edges of the GFRM jacket. Finally, these cracks extended along the height up to the middle of the column leading to the failure of the column. Jacketing of the specimens with sprayed GFRM enhanced the lateral load capacity of the columns with aspect ratio 2.0 and 4.0 , around $6 \%$ and $10 \%$, respectively. On the other hand, maximum drift ratio experienced in the seismic tests for these columns were $7 \%$ and $4 \%$, respectively. The increase in maximum drift of the columns C2-R and C4-R were around $250 \%$ and $166 \%$, respectively, with respect to their reference columns. The damages of the columns after tests are shown in Fig. 6. 


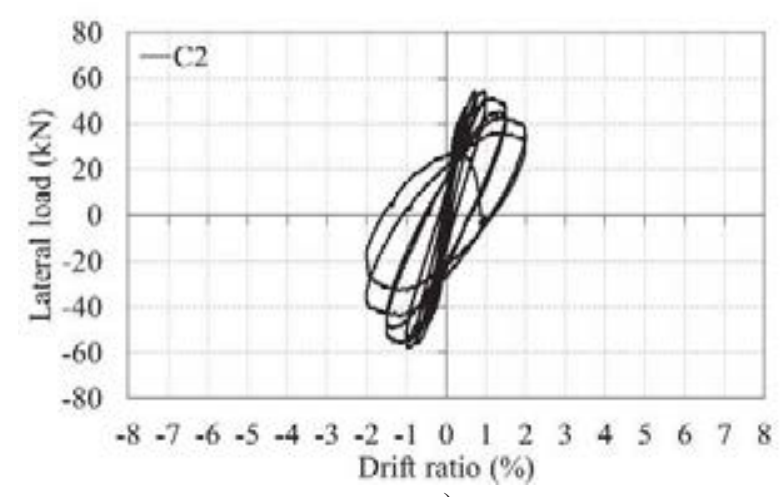

a)

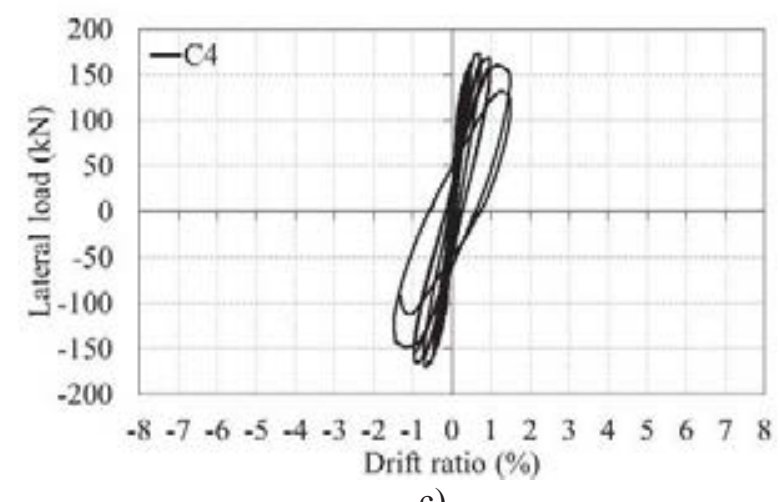

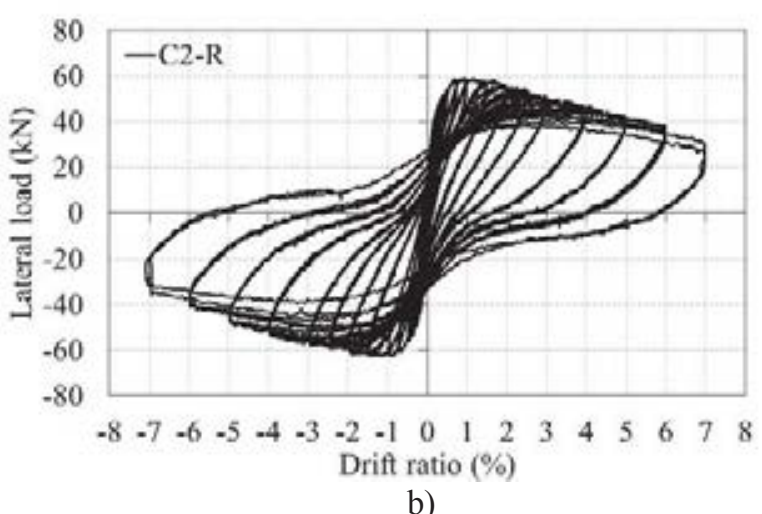

b)

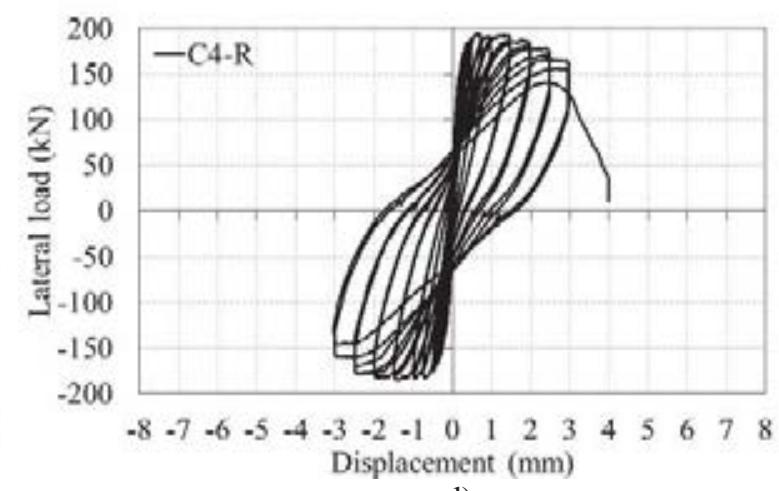

d)

Figure 4: Hysteretic response of the columns a) C2, b) C2-R, c) C4 and d) C4-R

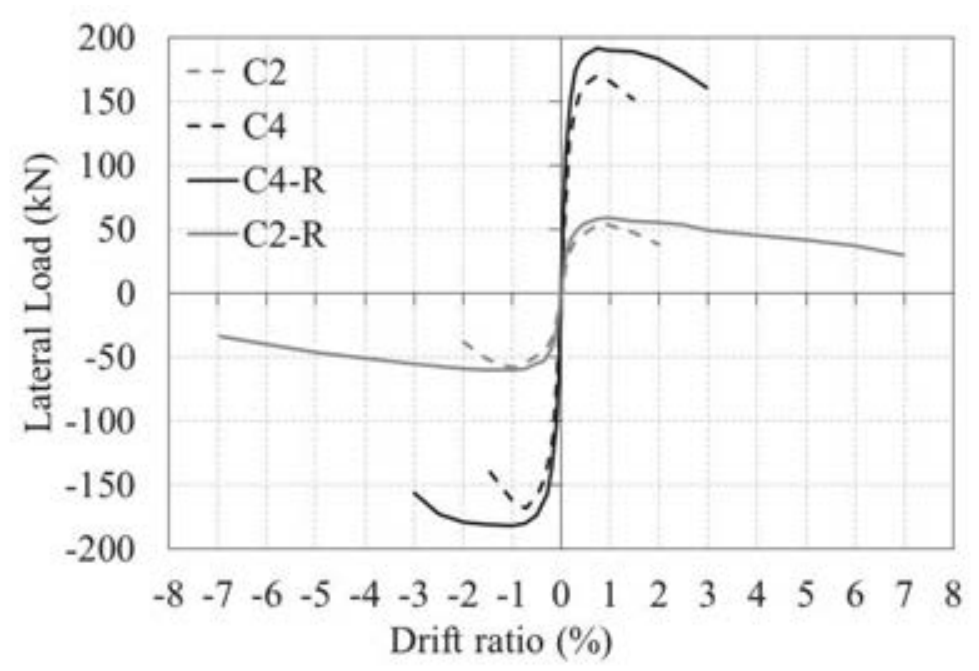

Figure 5: Envelope curves of the columns 


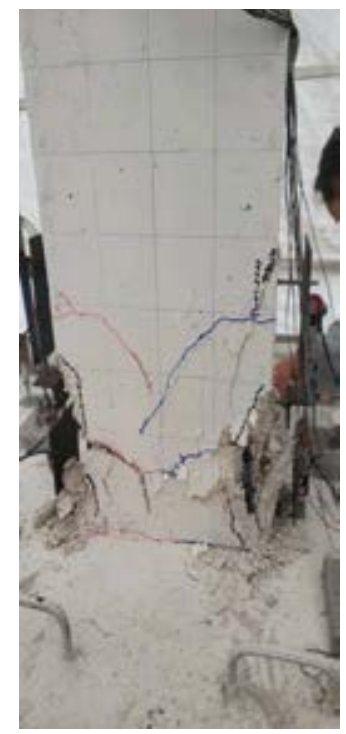

a)

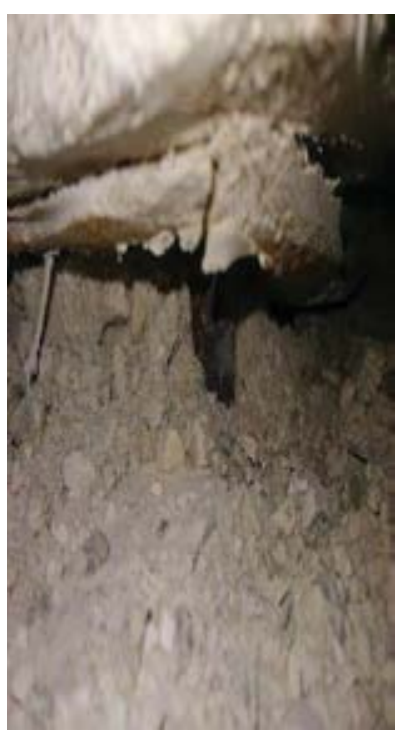

b)

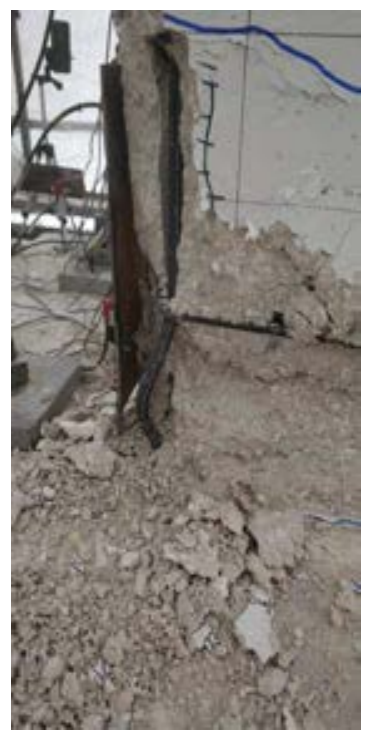

c)

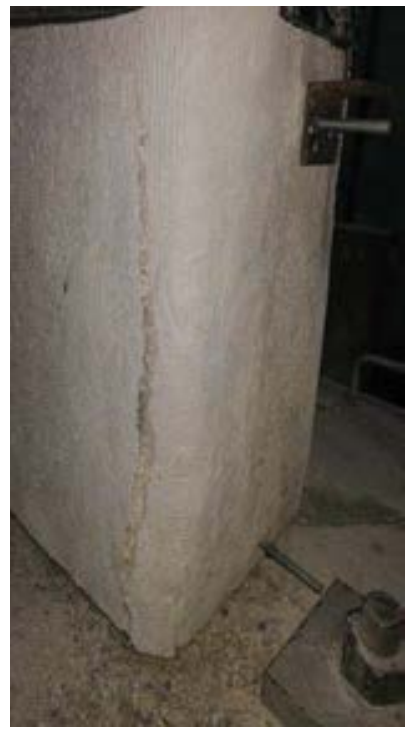

d)

Figure 6: Damages of the columns a) C2, b) C2-R c) C4 and d) C4-R at the end of the tests

Table 2: Summary of the test results

\begin{tabular}{lllllll}
\hline Specimen & $\begin{array}{l}\text { Failure } \\
\text { drift }^{\mathrm{a}} \\
(\%)\end{array}$ & $\begin{array}{l}\text { Maximum } \\
\text { lateral load in } \\
\text { pushing }(\mathrm{kN})\end{array}$ & $\begin{array}{l}\text { Maximum } \\
\text { lateral load in } \\
\text { pulling }(\mathrm{kN})\end{array}$ & $\begin{array}{l}\text { Yield } \\
\text { displacement, } \\
\Delta_{l}(\mathrm{~mm})\end{array}$ & $\begin{array}{l}\text { Ultimate } \\
\text { displacement, } \\
\Delta_{2}(\mathrm{~mm})\end{array}$ & $\begin{array}{l}\text { Ductility } \\
\text { factor, } \mu_{\Delta}\end{array}$ \\
\hline $\mathrm{C} 2$ & 1.8 & 58.1 & 53.2 & 5.8 & 28.9 & 5.0 \\
$\mathrm{C} 2-\mathrm{R}$ & 3.6 & 60.2 & 58.6 & 6.6 & 59.4 & 9.0 \\
$\mathrm{C} 4$ & 1.5 & 168.7 & 170.0 & 4.4 & 30 & 6.8 \\
$\mathrm{C} 4-\mathrm{R}$ & 3 & 181.7 & 191.4 & 4.0 & 60 & 15.0 \\
\hline
\end{tabular}

a drift corresponding to ultimate displacement (when the lateral strength was reduced to $80 \%$ of the peak value)

For a better comparison of the column performances in terms of ductility, displacement ductility factors $\left(\mu_{\Delta}\right)$ are calculated as an indicator of deformability. Displacement ductility factors are defined in this study as the ratio of ultimate displacement to the yield displacement. Yield displacement, $\Delta_{y}$, is the lateral displacement obtained from lateral load-lateral displacement $(P-\Delta)$ curve corresponding to the maximum lateral load on straight line joining origin and the point at $75 \%$ of the peak lateral load on ascending portion of the average envelope curve, and $\Delta_{u}$ is the ultimate lateral displacement obtained from $P-\Delta$ curve corresponding to $80 \%$ of the peak load on descending portion of average envelope curve. The yield and ultimate displacements are shown in Table 2 as well as corresponding displacement ductility factors. As seen in this table, sprayed GFRM jacketing of the columns doubled the ductility of the columns irrespective of the cross-sectional aspect ratio.

\section{CONCLUSIONS}

The main objective of this study is to investigate the efficiency of sprayed GFRM jacketing in terms of improving seismic performance of substandard columns with extended rectangular cross-sections. In accordance with this purpose, the preliminary results of an ongoing study are presented herein. Two reference and two sprayed GFRM jacketed sub-standard RC columns were tested under seismic loading with cross-sectional aspect ratios of 2.0 and 4.0. The following conclusions can be drawn from the study. 
- Application of sprayed GFRM jacketing resulted with a 6-10\% increase in lateral load capacity of the substandard columns.

- Due to the effective confinement provided by sprayed GFRM jacketing, the drift capacities of the columns were approximately doubled corresponding to 80 and $120 \%$ increase of displacement ductility for the columns with cross-sectional aspect ratios of 2.0 and 4.0 , respectively.

Further numerical and experimental studies are under progress for different cross-sections to shed some more light on the behavior of sprayed GFRM strengthening for substandard extended rectangular columns. The current results show that this cost-effective and easilyapplicable technique is promising for future practical applications.

\section{ACKNOWLEDGMENTS}

This research was granted in the scope of the bilateral collaboration between the research councils of Turkey (TUBITAK) and the Pakistan (PSF) under the grant number 118M261. The authors are most thankful to the Fibrobeton company for their continuous support from the construction phase of the specimens to the testing stage. The contributions of Dr. Cem Demir, Alihan Baltaci, Safiye Gundogan and Erkan Tore are also gratefully acknowledged.

\section{REFERENCES}

[1] R. D. Iacobucci, S. A. Sheikh, and O. Bayrak, Retrofit of square concrete columns with carbon fiber-reinforced polymer for seismic resistance. ACI Structural Journal, 100 (6), 785-794, 2003.

[2] M. Tapan, M. Comert, C. Demir, Y. Sayan, K. Orakcal and A. Ilki, Failures of structures during the October 23, 2011 Tabanlı (Van) and November 9, 2011 Edremit (Van) earthquakes in Turkey. Engineering Failure Analysis 34, 606-628, 2013.

[3] S. N. Bousias, T. C. Triantafillou, M. N. Fardis and L. Spathis, Fiber-reinforced polymer retrofitting of rectangular reinforced concrete columns with or without corrosion. ACI Structural Journal, 101 (4), 512-520, 2004.

[4] M. S. Memon, and S. A. Sheikh, Seismic resistance of square concrete columns retrofitted with glass fiber-reinforced polymer. ACI Structural Journal, 102 (5), 774, 2005.

[5] A. Ilki, C. Demir, I. Bedirhanoglu and N. Kumbasar, Seismic retrofit of brittle and low strength RC columns using fiber reinforced polymer and cementitious composites. $\mathrm{Ad}$ vances in Structural Engineering 12 (3), 325-347, 2009.

[6] H.F. Ghatte, M. Comert, C. Demir, M. Akbaba and A Ilki, Seismic retrofit of full-scale substandard extended rectangular RC columns through CFRP jacketing: test results and design recommendations, Journal of Composites for Construction 23 (1), 2018.

[7] M. Di Ludovico, A. Prota, G. Manfredi and E. Cosenza, Seismic strengthening of an under-designed RC structure with FRP. Earthquake Engineering \& Structural Dynamics, 37 (1), 141-162, 2008.

[8] M. Comert, C. Demir, A.O. Ates, K. Orakcal, and A. Ilki, "Seismic performance of three-storey full-scale sub-standard reinforced concrete buildings" Bulletin of Earthquake Engineering, 15 (8), 3293-3320, 2017. 
[9] E. Tore, M. Comert, C. Demir, A. Ilki, Collapse testing of full-scale RC buildings with or without seismic retrofit of columns with FRP jackets, TU1207 End of Action Conference, Budapest, 3-5 April, 2017.

[10] T.C. Triantafillou, C.G. Papanicolaou, P. Zissimopoulos, T. Laourdekis, Concrete confinement with textile reinforced mortar jackets. ACI Structural Journal, 103 (1), 2006.

[11] D.A. Bournas, P.V. Lontou, C.G. Papanicolaou, T.C. Triantafillou, Textile-reinforced mortar versus fiber reinforced polymer confinement in reinforced concrete columns. ACI Structural Journal, 104 (6), 2007.

[12] A.O. Ates, S. Khoshkholghi, E. Tore, M. Marasli, A. Ilki, Sprayed glass fiber reinforced mortar with or without basalt textile reinforcement for jacketing of low strength concrete prisms, ASCE, Journal of Composites for Construction, 23 (2), April, 2019.

[13] P.E. Mezrea, I.A. Yilmaz, E. Binbir, M. Ispir, I.E. Bal, and A. Ilki, External jacketing of unreinforced historical masonry piers with open-grid basalt reinforced mortar, ASCE Journal of Composites for Construction, 21 (3), Article Number: 04016110, 2017.

[14] Turkish Building Earthquake Code (TBEC), Disaster \& Emergency Management Authority, Ankara, Turkey, 2018.

[15] ASTM C109/109M-16a, Standard test method for compressive strength of hydraulic cement mortars. American Society for Testing and Materials. West Conshohocken, PA. Sec.4, Volume 04.01, 2016.

[16] ACI 374. 2R-13, Guide for testing reinforced concrete structural elements under slowly applied simulated seismic loads. American Concrete Institute, Farmington Hills, MI., 2013. 